\title{
Kernos
}

Revue internationale et pluridisciplinaire de religion grecque antique

$3 \mid 1990$

Varia

\section{Revue des rééditions et traductions}

\section{(2) OpenEdition \\ Journals}

Édition électronique

URL : http://journals.openedition.org/kernos/1038

DOI : 10.4000/kernos. 1038

ISSN : 2034-7871

\section{Éditeur}

Centre international d'étude de la religion grecque antique

\section{Édition imprimée}

Date de publication : 1 janvier 1990

ISSN : 0776-3824

Référence électronique

"Revue des rééditions et traductions », Kernos [En ligne], 3| 1990, mis en ligne le 19 avril 2011, consulté le 24 septembre 2020. URL : http://journals.openedition.org/kernos/1038 ; DOI : https:// doi.org/10.4000/kernos. 1038 


\section{4) Rééditions et traductions}

I riti di iniziazione, éd. par Julien RIES, trad. par Dario COSI et Luigi SAIBENE, Milano, Jaca Book, 1989 (Religioni), $252 \mathrm{p}$.

Marcel DETIENNE, Dionysos at Large, trad. par Arthur GOLDHAMMER, Cambridge, Harvard Univ. Press, 1989, 90 p. (Revealing Antiquity, 1).

-, Les Jardins d'Adonis, nouvelle édition augmentée d'une Postface de l'Auteur, Paris, Gallimard, 1989, $263 \mathrm{p}$.

Paul VEYNE, Did the Greeks Believe in their Myths? An Essay on the Constitutive Imagination, trad. par Paula WISSING, Univ. of Chicago Press, 1988, XII+161 p.

\section{5) Livres reçus à la rédaction}

Early Greek Cult Practice. Proceedings of the Fifth International Symposium at the Swedish Institute at Athens, 26-29 June 1986, éd. par Robin HÄGG, Nanno MARINATOS, Gullög C. NORDQUIST, Stockholm, 1988, 303 p., 264 fig. (Acta Instituti Atheniensis Regni Sueciae, Series in $4^{\circ}, 38$ ).

Louise BRUIT-ZAIDMAN et Pauline SCHMIDT-PANTEL, La religion grecque, Paris, A. Colin, 1989, 1 vol., 13,5 x 20,8 cm, 190 p., dessins et cartes (Coll. Cursus. Série "Histoire de l'Antiquité». ISBN : 2 200-33038-3.

Maria DARAKI, Une religiosité sans Dieu. Essai sur les stö̈ciens d'Athènes et Saint Augustin, Paris, Éd. La Découverte, 1989, 223 p.

Jacques DESAUTELS, Dieux et mythes de la Grèce ancienne. La mythologie gréco-romaine, Québec, Les Presses de l'Université de Laval, 1988, 648 p., 129 ill.

François LASSERRE, Nouveaux chapitres de littérature grecque (19471986), Genève, Droz, 1989, 275 p., 4 pl. (Publications de la Faculté des Lettres de l'Université de Lausanne).

Nicole LORAUX, Les expériences de Tirésias. Le féminin et l'homme grec, Paris, Gallimard, 1989, 400 p. (Essais).

—, Les mères en deuil, Paris, Éditions du Seuil, 1990 (La librairie du XXe siècle), $153 \mathrm{p}$.

Fabio MORA, Religione e religioni nelle Storie di Erodoto, Milano, Jaca Book, 1986 (Storia delle religioni).

Maria ROCCHI, Kadmos e Harmonia. Un matrimonio problematico, Roma, 'L'Erma' di Bretschneider, 1989, 144 p. (Storia delle religioni, 6). 